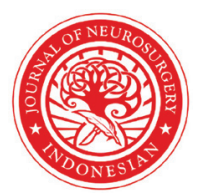

Indonesian Journal of Neurosurgery

\section{Risk factors of mortality due to traumatic brain injury in Marsidi Judono general hospital, Belitung, Indonesia}

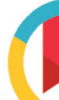

CrossMark

\author{
Jeffrey Chandra ${ }^{1 *}$, Widodo L. Tobing ${ }^{2}$
}

${ }^{1}$ General Practitioner, dr. H. Marsidi Judono General Hospital, Belitung, Indonesia;

${ }^{2}$ General Surgeon, dr. H. Marsidi Judono General Hospital, Belitung, Indonesia;

*Corresponding author:

Jeffrey Chandra;

General Practitioner, dr. H. Marsidi Judono General Hospital, Belitung, Indonesia;

jchandra@windowslive.com

Received: 2021-06-15

Accepted: 2021-10-24

Published: 2021-12-04

\section{ABSTRACT}

Introduction: Traumatic brain injury (TBI) is a global problem and the biggest cause of mortality and disability of all trauma cases. This study aimed to determine the characteristics and relationship between risk factors for TBI and its impact on mortality and also to provide epidemiological data related to TBI in Belitung regency.

Methods: A retrospective study was conducted using secondary data from the medical records of participants who met the inclusion and exclusion criteria at dr. H. Marsidi Judono General Hospital Belitung from January to December 2019. Data were analyzed as univariate, bivariate, and multivariate using binary logistic regression.

Results: Two hundred and seventy patients were included in this study. Men were more likely to have a TBI than women in all categories (65.9\%). The adolescent age group (33.7\%) followed by adults (31.5\%) were the largest contributors to TBI. Road traffic accident cases (86.7\%) dominated the incidence of TBI. The use of headgear was still lacking (36.7\%) while cases of road traffic accidents were high. The use of ambulances was lacking (10.4\%) compared to other vehicles. A total of 119 patients (44\%) were hospitalized in either the general ward or ICU with an average length of hospitalization was 3 days. Of all TBI cases, the mortality rate was $11.9 \%$. People with older age have a higher mortality rate compared to other age categories (OR 1.052; 95\% Cl: $1.001-1.106)$.

Conclusion: The mortality rate due to TBI reaches $11.9 \%$ in this region, with age as a statistically significant predictor of mortality due to TBI. Older patients tend to have a higher likelihood of death due to TBI. The data obtained can be used by general practitioners, disease preventative planners, and policymakers to reduce mortality due to TBI in Belitung regency.

Keywords: Belitung, risk factors of mortality, road traffic injury, traumatic brain injury.

Cite This Article: Chandra, J., Tobing, W.L. 2021. Risk factors of mortality due to traumatic brain injury in Marsidi Judono general hospital, Belitung, Indonesia. Indonesian Journal of Neurosurgery 4(3): 106-111. D0I: 10.15562/ijn.v4i3.163

\section{INTRODUCTION}

Traumatic brain injury (TBI) is an injury that affects the structure of the skull that causes physiological changes in the brain which can be caused by mechanical or non-mechanical external forces. ${ }^{1}$ TBI is a global problem and the biggest cause of mortality and disability of all trauma cases. ${ }^{2}$ The global incidence of TBI reaches 939 cases per 100,000 people and it is estimated that almost 70 million people in the world sustain a TBI every year. ${ }^{3}$ In Asia, India has the second-largest population in the world and accounts for more than a quarter of deaths from trauma globally which can be estimated for more than one million deaths, or it can be said that around $50 \%$ of all their cases are caused by TBI. ${ }^{4}$ In addition to death, disability after
TBI is very high. It is estimated that 15 20 people out of every 100,000 population aged under forty sustain severe disabilities each year. ${ }^{5}$

In Indonesia, although the epidemiological data of TBI is still lacking, we can see in one of this data from dr. Soetomo General Hospital, Surabaya, in 2009 until 2013, where the incidence of TBI reached 1,178 cases every year, with mortality rates ranging from $6.2 \%$ to $11.2 \% .^{1,6}$ According to their data, the mortality rate is higher than the international standard, which is $3 \%$ to 8\%. ${ }^{1}$ Another data from Global Burden of Diseases, Injuries, and Risk Factors (GBD) 2016 stated that the incidence of TBI in Indonesia in that same year reached 670 thousand cases or around 264 cases per 100,000 population. This number indicates an increase of incidences for about $25 \%$, compared to the incidences in $1990 .^{7}$ The increasing incidences of TBI worldwide, including Indonesia, is linked to the increasing use of motorized vehicles which is associated with traffic accidents as the main cause, followed by falls and violence. $^{8}$ From Riskesdas 2018, the proportion of TBI in Indonesia was 11.9\%. Our province itself, Bangka Belitung, was in $10^{\text {th }}$ place of all provinces in Indonesia, where the proportion was greater than the national average, which was $14.2 \% .^{9}$

Especially in Belitung, there is no comprehensive epidemiological data on TBI even though the incidence is quite high. This research is expected to be sufficiently representative in providing an overview of TBI cases in Belitung as our hospital, dr. H. Marsidi Judono General 
Hospital is the largest hospital and a regional referral center in the Belitung regency. We hope that this research may give a contribution to epidemiological data on brain injury at local, regional, and national levels, and also can be used as a basis for further research ideas and finally be useful in the making and implementing local and central government policies.

\section{METHODS}

This study was held at dr. H. Marsidi Judono General Hospital Belitung, which is the regional referral center in Belitung regency. This study was a retrospective cohort study with secondary data from the medical records of TBI patients who came to the emergency department from January to December 2019. Sampling was carried out using a non-probability sampling technique. The study population was all TBI patients at our hospital. The inclusion criterias were patients diagnosed with mild (GCS 13 - 15), moderate (GCS 9 - 12), and severe (GCS $3-8$ ) TBI based on the Glasgow Coma Scale (GCS); TBI patients with multiple trauma; TBI patients older than five years. Patients with wounds that were in the head area but not diagnosed with TBI and patients with incomplete medical records were not included in this study.

The medical record is used to obtain information regarding gender, age, GCS value at the time of arrival, cause of TBI (traffic or non-traffic accident), wearing of head protection (wearing or not wearing), mode of transportation used to go to the hospital (ambulance or other vehicles), hospitalization (not hospitalized, inpatient in the general ward or inpatient in the ICU), length of stay, and the patient's outcome (improving or dying). For epidemiological data, variables of age and length of stay are divided into subgroups. Age was divided into children (5 - 11 years), adolescents ( $12-25$ years), adults ( $26-45$ years), elders ( $46-65$ years), and seniors (> 65 years) categories. Length of stay was divided into no hospitalization (0 day), 1 - 2 days, 3 - 5 days, and more than 6 days. Motorcycle injuries, car injuries, and pedestrian injuries were within traffic accidents, whereas falls, assaults, and other injuries were included in non-traffic accidents.
Data obtained were analyzed using SPSS version 23. Bivariate logistic regression was used to determine the relationship between each variable with the patient's outcome and multivariate logistic regression was used to estimate the relationship between all variables and the patient's outcome. A p-value $<0.05$ was considered statistically significant.

\section{RESULTS}

A total of 333 samples were obtained from the medical records unit. Sixty-three samples were excluded due to incomplete medical record data, leaving us with 270 samples.

Two hundred twenty-five of them are mild TBI (83.3\%), followed by severe TBI in 26 cases $(9.6 \%)$, and the remainder (7.1\%) are moderate TBI. Men dominated the incidence of TBI in as many as 178 patients (65.9\%). The mean age of the patients in this study is 33.4 years, with the youngest being 6 years to the oldest 98 years. Adolescents (12 - 25 years) and adults (26 - 45 years), which are respectively 91 patients and 85 patients, are the group who sustain the most brain injury.

Motorcycle accidents were the most common cause of TBI (222 cases, 94.9\%) of all traffic accidents. Falls accidents (24 cases, $66.7 \%$ ) were the most common cause of all non-traffic accident cases (Fig. 1A and Fig. 1B). Motorcyclists who wear head protectors/helmets were only $99(36.7 \%)$ out of 222 cases, with the male motorcyclist, as many as 87 patients are the frequent ones who do not wear helmets (70.7\%) (Fig. 1C). The most common mode of transportation to go to the hospital after sustaining TBI is other vehicles than ambulances, with as many as

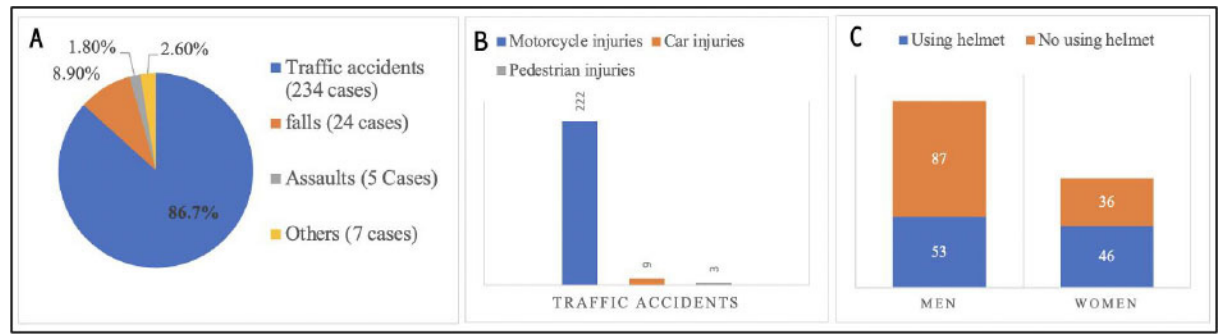

Figure 1. A. Causes of TBI; B. Types of traffic accidents; C. Helmet use on motorcycle riders based on gender.
242 cases $(89.6 \%)$.

After the medical assessment of all TBI cases, 119 patients were hospitalized with 103 patients being treated in the general ward $(38.1 \%)$ and 16 patients being admitted to the ICU (5.9\%). Mild brain injury cases were the most frequently treated in the general ward (90 patients, $40 \%$ ) while the ICU was the most frequent place of care for severe TBI cases (12 patients, $46.2 \%$ ). The duration of hospitalization varied, from the shortest, which is one day, to the longest, which is twelve days, with the average duration of hospitalization for all cases being 3.1 days. The mean duration of hospitalization for cases that were admitted to the ICU alone is 2.3 days. After receiving the medical intervention, both hospitalized and non-hospitalized patients, as much as 238 patients (88.1\%), showed some improvement in their condition. This number is dominated by mild TBI cases (98.2\%). Meanwhile, the number of deaths due to TBI was 32 cases (11.9\%) with 24 of them (92.3\%) were severe TBI cases. (Table 1 and Table 2).

There were 16 cases of death due to TBI that occurred in the emergency department. This number included patients who had received medical intervention and patients who have already dead on arrival. Of the 119 patients treated, as many as 103 patients (87\%) had improvement on their level of consciousness and the remaining (13\%) had worsened on their level of consciousness until they were finally death. Table 1 provides information that the elderly group accounted for the most cases of death with 12 cases (37.5\%) and followed by the adolescents group with 10 cases (31.3\%). 
Bivariate test results with binary logistic regression showed that age $(\mathrm{p}$ $=0.009)$, head protection $(\mathrm{p}=0.005)$, mode of transportation ( $\mathrm{p}=0.028)$, hospitalization $(\mathrm{p}=0.001)$, and GCS value $(\mathrm{p}=0.001)$ influenced the patient's causes of TBI $(\mathrm{p}=0.224)$, and duration of hospitalization $(\mathrm{p}=0.827)$ did not outcome. Meanwhile, gender ( $\mathrm{p}=0.058)$,

significantly influence the outcome (Table 3). Multivariate analysis with binary logistic regression showed that age was the only variable that significantly affected the risk of death from brain injury, where older age led to a higher risk of death from brain injury with OR 1.052 (95\% CI: 1.001 - 1.106).

Table 1. Demographic characteristic of samples.

\begin{tabular}{|c|c|c|c|c|c|c|}
\hline \multirow{2}{*}{ Variable } & \multicolumn{2}{|c|}{ Improve } & \multicolumn{2}{|c|}{ Death } & \multicolumn{2}{|c|}{ Total } \\
\hline & $\mathbf{n}$ & $\%$ & $\mathbf{n}$ & $\%$ & $\mathbf{n}$ & $\%$ \\
\hline \multicolumn{7}{|l|}{ Gender } \\
\hline Men & 152 & 63.9 & 26 & 81.3 & 178 & 65.9 \\
\hline Women & 86 & 36.1 & 6 & 18.8 & 92 & 34.1 \\
\hline \multicolumn{7}{|l|}{ Age group (years) } \\
\hline Children $(5-11)$ & 12 & 5.0 & 2 & 6.3 & 14 & 5.2 \\
\hline Adolescents (12 - 25) & 81 & 34.0 & 10 & 31.3 & 91 & 33.7 \\
\hline Adults $(26-45)$ & 82 & 34.5 & 3 & 9.4 & 85 & 31.5 \\
\hline Elders $(46-65)$ & 48 & 20.2 & 12 & 37.5 & 60 & 22.2 \\
\hline Seniors $(>65)$ & 15 & 6.3 & 5 & 15.6 & 20 & 7.4 \\
\hline \multicolumn{7}{|l|}{ Causes of TBI } \\
\hline Traffic accident & 204 & 85.7 & 30 & 93.8 & 234 & 86.7 \\
\hline Non-traffic accident & 34 & 14.3 & 2 & 6.2 & 36 & 13.3 \\
\hline \multicolumn{7}{|l|}{ Head protection } \\
\hline No use & 143 & 60.1 & 28 & 87.5 & 171 & 63.3 \\
\hline Use & 95 & 39.9 & 4 & 12.5 & 99 & 36.7 \\
\hline \multicolumn{7}{|l|}{ Mode of transportation } \\
\hline Other vehicle & 217 & 91.2 & 25 & 78.1 & 242 & 89.6 \\
\hline Ambulance & 21 & 8.2 & 7 & 21.9 & 28 & 10.4 \\
\hline \multicolumn{7}{|l|}{ Hospitalization } \\
\hline No hospitalization & 135 & 56.7 & 16 & 50.0 & 151 & 55.9 \\
\hline General ward & 102 & 42.0 & 1 & 3.1 & 103 & 38.2 \\
\hline Intensive care unit & 1 & 0.4 & 15 & 46.9 & 16 & 5.9 \\
\hline \multicolumn{7}{|l|}{ Length of stay } \\
\hline 0 day & 135 & 56.7 & 16 & 50.0 & 151 & 55.9 \\
\hline $1-2$ days & 45 & 18.9 & 10 & 31.3 & 55 & 20.4 \\
\hline $3-5$ days & 49 & 20.5 & 4 & 12.5 & 53 & 19.6 \\
\hline$>6$ days & 9 & 3.8 & 2 & 6.3 & 11 & 4.1 \\
\hline \multicolumn{7}{|l|}{ GCS } \\
\hline Mild TBI & 221 & 92.9 & 4 & 12.5 & 225 & 83.3 \\
\hline Moderate TBI & 15 & 6.3 & 4 & 12.5 & 19 & 7.1 \\
\hline Severe TBI & 2 & 0.8 & 24 & 75 & 26 & 9.6 \\
\hline
\end{tabular}

\section{DISCUSSION}

Belitung regency based on data from the Central Bureau of Statistics of Belitung in 2019 , is inhabited by 173,717 people, and it is estimated that the incidence of TBI in Belitung reached 192 cases per 100,000 population. ${ }^{10}$ The number of cases found in this region is less than data from Global Burden of Diseases, Injuries, and Risk Factors (GBD) 2016, which provides an estimated incidence of TBI in Indonesia that is 264 cases per 100,000 population. $^{7}$ In Indonesia, information about the incidence of TBI is still focused on local studies especially on teaching hospitals such as RSUP Sanglah Denpasar, which found more than 2,000 TBI cases. ${ }^{11}$ With this very limited and centralized data, a better recording and reporting system is needed in the future so that the incidence of brain injury on a national scale can be described.

Men dominated the incidence of TBI in this study. In this study, men were 1.9 times more likely to sustain TBI than women. This is consistent with several demographic studies conducted abroad. Munivenkatappa et al. conducted a study that questioned whether gender will influence the outcome of patients with TBI. Their study showed the ratio of men to women patients is $4.5: 1$, with the most common causes of TBI were traffic accidents and fights. ${ }^{12}$ In general, men were more likely to experience recurrent traffic accidents due to their higher mobility than women. ${ }^{13}$

Adolescents and adults are the largest contributors to TBI. It is associated with higher mobility such as working and schooling where the use of motorized vehicles in countries with lower middle income is still quite high so that the tendency for traffic accidents is also increased..$^{14}$ In several studies, age variable

Table 2. Overview of hospitalization and mortality against the degree of TBI.

\begin{tabular}{|c|c|c|c|c|c|c|c|c|}
\hline \multirow{2}{*}{ Variable } & \multicolumn{2}{|c|}{ Mild TBI } & \multicolumn{2}{|c|}{ Moderate TBI } & \multicolumn{2}{|c|}{ Severe TBI } & \multicolumn{2}{|c|}{ Total } \\
\hline & $\mathbf{n}$ & $\%$ & $\mathbf{n}$ & $\%$ & $\mathbf{n}$ & $\%$ & $\mathbf{n}$ & $\%$ \\
\hline \multicolumn{9}{|l|}{ Hospitalization } \\
\hline No hospitalization & 135 & 60 & 3 & 15.8 & 13 & 50 & 151 & 55.9 \\
\hline General ward & 90 & 40 & 12 & 63.2 & 1 & 3.8 & 103 & 38.1 \\
\hline Intensive care unit & 0 & 0.0 & 4 & 21.1 & 12 & 46.2 & 16 & 5.9 \\
\hline Mortality $^{* *}$ & 4 & 1.8 & 4 & 21.1 & 24 & 92.3 & 32 & 11.9 \\
\hline
\end{tabular}

${ }_{* *}$ : Death on arrival and after hospitalization 
Table 3. Bivariate logistic regression and multivariate analysis.

\begin{tabular}{|c|c|c|c|c|c|c|}
\hline \multirow{2}{*}{ Covariates } & \multicolumn{3}{|c|}{ Bivariate association } & \multicolumn{3}{|c|}{ Multivariate association } \\
\hline & $\mathbf{P}$ & OR & $95 \% \mathrm{Cl}$ & $\mathbf{P}$ & OR & $95 \% \mathrm{Cl}$ \\
\hline \multicolumn{7}{|l|}{ Gender } \\
\hline Men & 0.058 & 2.452 & $0.971-6.191$ & 0.810 & 1.260 & $0.191-8.324$ \\
\hline Women & 0.058 & 0.480 & $0.162-1.030$ & 0.810 & 0.794 & $0.120-5.243$ \\
\hline Age & 0.009 & 1.025 & $1.006-1.044$ & 0.044 & 1.052 & $1.001-1.106$ \\
\hline \multicolumn{7}{|l|}{ Causes } \\
\hline Traffic accident & 0.224 & 2.500 & $0.571-10.95$ & 0.232 & 1018 & $0.003-3805$ \\
\hline Non-traffic accident & 0.224 & 0.400 & $0.091-1.751$ & 0.232 & 0.000 & $0.000-366.5$ \\
\hline \multicolumn{7}{|l|}{ Head protection } \\
\hline Use & 0.005 & 4.650 & $1.580-13.68$ & 0.776 & 0.197 & $0.197-8.841$ \\
\hline No use & 0.005 & 0.215 & $0.073-0.633$ & 0.776 & 0.113 & $0.113-5.083$ \\
\hline \multicolumn{7}{|l|}{ Transportation } \\
\hline Other vehicle & 0.028 & 0.346 & $0.134-0.894$ & 0.183 & 0.305 & $0.305-508.2$ \\
\hline Ambulance & 0.028 & 2.893 & $7.484-0.183$ & 0.183 & 0.002 & $0.002-3.281$ \\
\hline \multicolumn{7}{|l|}{ Hospitalization } \\
\hline No & 0.000 & 0.008 & $0.001-0.064$ & 0.104 & 0.000 & $0.000-4.448$ \\
\hline General ward & 0.000 & 0.001 & $0.000-0.011$ & 0.069 & 0.000 & $0.000-1.631$ \\
\hline Intensive care unit & 0.000 & 126.6 & $15.66-1022$ & 0.104 & 0.225 & $0.225-9983$ \\
\hline Length of stay & 0.827 & 0.979 & $0.813-1.180$ & 0.121 & 0.058 & $0.058-1.391$ \\
\hline \multicolumn{7}{|l|}{ Severity of TBI } \\
\hline Mild brain injury & 0.000 & 0.002 & $0.000-0.009$ & 0.110 & 0.000 & $0.000-16.18$ \\
\hline Moderate brain injury & 0.000 & 0.022 & $0.004-0.137$ & 0.214 & 0.000 & $0.000-224.1$ \\
\hline Severe brain injury & 0.000 & 663.0 & $115.3-3811$ & 0.110 & 0.062 & $0.062-9269$ \\
\hline
\end{tabular}

CI: Confidence interval; OR: Odds ratio

greatly influences the severity, progression, and prognosis of a TBI. ${ }^{15,16}$ Older age and early childhood ( $<6$ years old) have anatomical and physiological differences that are not negligible when compared to adult patients. It makes the impact of morbidity and mortality in this age group higher than in other groups. ${ }^{17}$

The use of helmets for motorcyclists in Bangka Belitung Province according to the data from Riskesdas 2018 is divided into three categories, $41.9 \%$ always wear a helmet, $42.4 \%$ sometimes wear a helmet and the remain do not wear a helmet. Especially in Belitung regency, there is no specific data, but from this study, it is found that only about $30 \%$ of motorcycle accident victims who wore helmets suffered a TBI. Research from Lahdimawan et al. illustrated the importance of using head protection both when working and driving a vehicle, especially motorbikes, where this study showed a significant relationship between head protection variables and the severity of TBI. ${ }^{18}$

In the case of TBI, an ambulance equipped with standardized health personnel and facilities is an important factor to prevent secondary TBI (increased intracranial pressure, hypotension, hypoxia, hyperthermia, and seizures) when transferring a patient to the emergency department. ${ }^{19}$ In this study, the majority of patients with mild TBI arrived by vehicle other than an ambulance (92.4\%) whereas only 28 patients $(10.4 \%)$ of all TBI cases used ambulances. Several factors such as the location of the accidents, which is far from health facilities, panic from the patient's family/local residents, and the lack of public knowledge about the importance of good patient transfers, are thought to have caused the low use of ambulances in Belitung regency.

Duration of hospitalization can be influenced by failure in treatment, the severity of disease, limitations in medical facilities, and inadequate treatment of a disease. ${ }^{20}$ Research at a public hospital in Sumba, East Nusa Tenggara, where the condition of the hospital was not much different from the hospital where this study was conducted, showed that the mean duration of hospitalization for mild TBI was 2 days, moderate TBI was 3 days, and severe TBI was 5 days. ${ }^{21}$ At the hospital where this study was conducted, moderate and severe TBI or TBI with rapid progression, often treated with pharmacology alone. Limited facilities and the absence of a neurosurgeon in Belitung regency make the medical intervention of TBI cases not optimal so that the duration of treatment in the hospital will increase and the cost of treatment becomes even greater.

The mortality rate of TBI in this study was $11.9 \%$. Most of the deaths were severe TBI cases, which was $88.9 \%$, while its incidence of all cases was $8.9 \%$. Compared with the existing literature in Indonesia, according to the research of Tjahjadi et al., the incidence of severe TBI in Indonesia was between $6 \%$ and $12 \%$ with a mortality rate range between $25 \%$ and $37 \% .^{22}$ Another study conducted at dr. Soetomo General Hospital Surabaya, with the availability of facilities and neurosurgeons, showed the death rate due to TBI was $6.2 \%$ to $11.2 \% .^{1}$ In the hospitals in remote areas such as Umbu Rara Meha General Hospital, Waingapu with conditions similar to the hospital where this study was conducted, the mortality rate due to 
TBI was $2.2 \%{ }^{21}$ Compared with some existing literature, the death rate from TBI in Belitung regency was higher, especially when it is compared to the areas that have better treatment ability and other areas with similar health facilities.

Prabhakaran et al. demonstrated a significant association between secondary transfers (non-trauma hospitals without a specialist transferring a patient to the trauma center) and decreased survival rates. $^{23}$ Guidelines on the prehospital management of TBI from Brain Trauma Foundation 2018 recommend transferring the patients directly to a hospital with a neurosurgical facility for the efficiency of time in managing TBI. The neurosurgical facilities in question are the availability of computed tomography scans, intracranial pressure monitors, the availability of neurosurgeons, and the availability of ICU. ${ }^{24}$

Increasing age makes patients more susceptible to death after TBI. Several studies have suggested an association between older age and increased mortality from TBI. The mortality rate for patients aged $>65$ years in this study was $8.5 \%$, higher than the mortality rate for patients aged under 65 years, which was $3.87 \%$. This is in accordance with the research of Salottolo et al., which showed an increase in mortality with increasing age. ${ }^{25}$ Thus, increasing age independently increases mortality and older age can also be used to predict mortality from TBI by determining the level of consciousness. ${ }^{26}$

\section{CONCLUSION}

The mortality rate from TBI cases in Belitung regency reached $11.9 \%$ with age variable as a predictor which had a significant effect on this. The older the patient gets, the higher the likelihood of death from TBI. The absence of neurosurgeons in our hospitals as the regional referral center for Belitung regency and the limited hospital facilities make the management of TBI cases are not optimal, resulting in increased mortality. The data obtained in this study can be used by clinical practitioners, disease preventative planners, and policymakers to reduce the mortality rate of TBI in Belitung regency.

\section{ACKNOWLEDGMENTS}

The authors are grateful to the director of Marsidi Judono General Hospital Belitung who fully supported this research for the benefit of hospital planning in the future.

\section{FUNDING}

There is no funding.

\section{CONFLICT OF INTEREST}

The author declares no conflict of interest.

\section{AUTHOR CONTRIBUTION}

The first author provided the idea of the research and study design, contributed to data collection, analyzing and interpreting the data, and participated in writing the manuscript. The second author gave corrected the manuscript and also provided input on the interpretation of the results.

\section{REFERENCES}

1. Rosyidi RM, Priyanto B, Laraswati NKP, Islam AA, Hatta M, Bukhari A, et al. Characteristics and clinical outcome of traumatic brain injury in Lombok, Indonesia. Interdisciplinary Neurosurg. 2019; 18: 100470. https://doi. org/10.1016/j.inat.2019.04.015.

2. Rubiano AM, Carney N, Chesnut R, Puyana JC. Global neurotrauma research challenges and opportunities. Nature. 2015; 527: S194 - S197.

3. Dewan MC, Rattani A, Gupta S, Baticulon RE, Hung Y-C, Punchak M, et al. Estimating the global incidence of traumatic brain injury. J Neurosurg. 2018; 1 - 18. https://doi. org/10.3171/2017.10.JNS17352.

4. Maas AIR. Traumatic brain injury in India: A big problem in need of data. Neurol India. 2017; 65(2): 257 - 258. https://doi.org/10.4103/00283886.201848.

5. Fleminger S, Ponsford J. Long term outcome after traumatic brain injury: More attention needs to be paid to neuropsychiatric functioning. BMJ. 2005; 331(7530): $1419-20$. https://doi.org/10.1136/bmj.331.7530.1419.

6. Faried A, Bachani AM, Sendjaja AN, Hung YW, Arifin MZ. Characteristics of moderate and severe traumatic brain injury of motorcycle crashes in Bandung, Indonesia. World Neurosurg. 2017; 100: 195 - 200. https://doi. org/10.1016/j.wneu.2016.12.133.

7. James SL, Bannick MS, Montjoy-Venning WC, Lucchesi LR, Dandona L, Dandona R, et al. Global, regional, and national burden of traumatic brain injury and spinal cord injury, 1990 - 2016: A systematic analysis for the Global Burden of Disease Study 2016. Lancet Neurol. 2019; 18(1): 56 - 87. https://doi. org/10.1016/S1474-4422(18)30415-0.
8. Wong GKC, Yeung JHH, Graham CA, Zhu X-L, Rainer TH, Poon WS. Neurological outcome in patients with traumatic brain injury and its relationship with computed tomography patterns of traumatic subarachnoid hemorrhage. J Neurosurg. 2011; 114(6): 1510 5. https://doi.org/10.3171/2011.1.JNS101102.

9. Badan Penelitian dan Pengembangan Kesehatan. Laporan Nasional Riskesdas 2018. Jakarta: Lembaga Penerbit Badan Penelitian dan Pengembangan Kesehatan; 2019.

10. BPS Kabupaten Belitung. Kabupaten Belitung Dalam Angka 2020. BPS Kabupaten Belitung, editor. BPS Kabupaten Belitung; 2020.

11. Sudira PG. Post concussion syndrome: Kondisi underdiagnosis pasca cedera kepala. In: Arimbawa K, Sudira PG, Samatra DPGP, Laksmidewi AAAP, Andryana IMO, Susilawathi NM, et al. (Eds.) Bali Neurology Update 2017. Denpasar: Udayana University Press; 2017. p. $27-41$.

12. Munivenkatappa A, Agrawal A, Shukla DP, Kumaraswamy D, Devi BI. Traumatic brain injury: Does gender influence outcomes? Int J Crit Illn Inj Sci. 2016; 6(2): 70 - 3. https://doi. org/10.4103/2229-5151.183024.

13. Kraus JF, Peek-Asa C, McArthur D. The independent effect of gender on outcomes following traumatic brain injury: A preliminary investigation. Neurosurg Focus. 2000; 8(1): e5. https://doi.org/10.3171/foc.2000.8.1.156.

14. Hyder AA, Wunderlich CA, Puvanachandra P, Gururaj G, Kobusingye OC. The impact of traumatic brain injuries: A global perspective. NeuroRehabilitation. 2007; 22(5): 341 - 53.

15. Biswas RK, Kabir E, King R. Effect of sex and age on traumatic brain injury: A geographical comparative study. Arch Public Health. 2017; 75(1): 43. https://doi.org/10.1186/s13690-0170211-y.

16. Syahrul, Imran, Fajri N. Clinical characteristics of traumatic brain injury patients in Dr. Zainoel Abidin Public Hospital Banda Aceh, Indonesia. Bali Med J. 2020; 9(1): 194 - 200. https://doi. org/10.15562/bmj.v9il.1726.

17. Brickler T, Morton P, Hazy A, Theus MH. Age-dependent responses following traumatic brain injury. In: Gorbunov NV, Long JB (Eds.) Traumatic Brain Injury - Pathobiology, Advanced Diagnostics and Acute Management. InTech; 2018. https://doi.org/10.5772/ intechopen.71344.

18. Ladhimawan ITF, Suhendra A, Wasilah S. Hubungan penggunaan helm dengan beratnya cedera kepala akibat kecelakaan lalu lintas darat di RSUD Ulin bulan Mei - Juli 2013. Jurnal Berkala Kedokteran. 2014;10(2).

19. Nathanson $\mathrm{MH}$, Andrzejowski J, Dinsmore J, Eynon CA, Ferguson K, Hooper T, et al. Guidelines for safe transfer of the brain-injured patient: Trauma and stroke, 2019: Guidelines from the Association of Anaesthetists and the Neuro Anaesthesia and Critical Care Society. Anaesthesia. 2020; 75(2): 234 - 46. https://doi. org/10.1111/anae.14866.

20. O'Keefe GE, Jurkovich GJ, Maier RV. Defining excess resource utilization and identifying associated factors for trauma victims. $J$ 
Trauma. 1999; 46(3): 473 - 8. https://doi. org/10.1097/00005373-199903000-00023.

21. Putra MB. Karakteristik pasien cedera kepala di Rumah Sakit Umum Daerah (RSUD) Umbu Rara Meha Waingapu periode 1 Januari 2017 31 Desember 2018. Intisari Sains Medis. 2019; 10(2): 511 - 515.

22. Tjahjadi M, Arifin MZ, Gill AS, Faried A. Early mortality predictor of severe traumatic brain injury: A single center study of prognostic variables based on admission characteristics. Indian J Neurotrauma. 2013; 10(1): 3 - 8.

23. Prabhakaran K, Petrone P, Lombardo G, Stoller C, Policastro A, Marini CP. Mortality rates of severe traumatic brain injury patients: Impact of direct versus nondirect transfers. J Surg Res. 2017; 219: 66 - 71. https://doi.org/10.1016/j. jss.2017.05.103.

24. Badjatia N, Carney N, Crocco TJ, Fallat ME, Hennes HMA, Jagoda AS, et al. Guidelines for prehospital management of traumatic brain injury 2nd edition. Prehosp Emerg Care. 2008; 12(Suppl 1): S1 - 52. https://doi. org/10.1080/10903120701732052.

25. Salottolo K, Levy AS, Slone DS, Mains CW, BarOr D. The effect of age on Glasgow Coma Scale score in patients with traumatic brain injury. JAMA Surg. 2014; 149(7): 727 - 34. https://doi. org/10.1001/jamasurg.2014.13.
26. Timmons SD, Bee T, Webb S, Diaz-Arrastia $\mathrm{RR}$, Hesdorffer D. Using the abbreviated injury severity and Glasgow Coma Scale scores to predict 2-week mortality after traumatic brain injury. J Trauma. 2011; 71(5): $1172-8$. https:// doi.org/10.1097/TA.0b013e31822b0f4b.

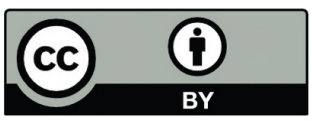

This work is licensed under a Creative Commons Attribution 